\title{
GRAIN COMPOSITION AND FUNCTIONAL INGREDIENTS OF BARLEY VARIETIES CREATED IN LATVIA
}

\author{
Vita Šterna ${ }^{1 \#}$, Sanita Zute ${ }^{1}$, and Ida Jākobsone ${ }^{2}$ \\ ${ }^{1}$ State Stende Cereal Breeding Institute, „Dižzemes”, Dižstende, Lībagi Civil Parish, Talsi County, LV-3258, LATVIA; \\ vitasterna@inbox.lv \\ ${ }^{2}$ Faculty of Chemistry, University of Latvia, Kr. Valdemāra iela 48, Rīga, LV-1013, LATVIA \\ \# Corresponding author
}

Communicated by Daina Kārkliṇa

\begin{abstract}
Cereals, including barley, have been recognised as functional foods that provide beneficial effect on the health of the consumer and decrease the risk of various diseases. The aim of investigation was to determine the grain composition of barley varieties and perspective breeding lines bred in Latvia and to evaluate its functional ingredients. The results of analysis showed that protein content among varieties ranged from $106.6-146.8 \mathrm{~g} \cdot \mathrm{kg}^{-1}$, total dietary fibre $187.4-208.2 \mathrm{~g} \cdot \mathrm{kg}^{-1}$, $\beta$-glucans $42.8 \mathrm{~g}-49.4 \mathrm{~g} \cdot \mathrm{kg}^{-1}$, and amount of $\alpha$-tocopherol $6.03-8.93 \mathrm{mg} \cdot \mathrm{kg}^{-1}$. The sum of essential amino acids in barley grain samples was from $32.90 \mathrm{~g} \cdot \mathrm{kg}^{-1}$ to $38.71 \mathrm{~g} \cdot \mathrm{kg}^{-1}$. All varieties of hulled and hulless barley grain were found to be sources of protein with high biological value. Comparison of barley varieties bred in Latvia suggests that variety 'Kornelija' outperforms others in protein, dietary fibre and micronutrient content.
\end{abstract}

Key words: Hordeum vulgare, amino acids, $\beta$-glucans, dietary fibre, $\alpha$-tocopherol.

Barley (Hordeum vulgare L.) has been commonly cultivated for centuries due to its versatility, ability to adapt to unfavourable climate and soil conditions, and superior properties for the malting and brewing industries. In recent years, cereals have been recognised as functional foods, because their fibre, mineral and antioxidant contents can provide beneficial effect on the health of the consumer and decrease the risk of various diseases. The increased interest in barley as a human food ingredient results from studies that have shown barley to be an excellent source of dietary fibre and, in particular, $\beta$-glucan.

The nutritional quality of dietary protein is related to the concentration of essential amino acids in the protein, compared with their nutritional requirements in the human body (Anonymous, 2007). Foodstuffs that lack essential amino acids might be poor sources of protein equivalents, as the body tends to deaminate the amino acids obtained, converting proteins into fats and carbohydrates. The amino acid score can be used to predict biological value or the anticipated ability of the absorbed test protein to fulfil human amino acid requirements (Anonymous, 2007).

Barley kernels contain low levels of lipids - approximately $2-4 \%$ of total grain weight (Welch, 1978). Barley contains the highest amount of fat-soluble vitamin E (tocols), comparing with major cereals (Kerckhoffs et al., 2002). Fat-soluble vitamin E is an important antioxidant in foods and its concentration is positively correlated with oil content (Newman and Newman, 2008). Barley grains contain all eight isomers - four tocopherols $(\alpha-\mathrm{T}, \beta-\mathrm{T}, \gamma$-T and-T) and four tocotrienols $(\alpha-\mathrm{T} 3, \beta-\mathrm{T} 3, \gamma-\mathrm{T} 3$ and $\delta$-T3) (Morrison, 1978; Zielinski, 2001). Andersson et al. (2008) reported that the average proportion of tocotrienol was $76.8 \%$ of total tocol content, indicating that barley is one of the richest sources of tocotrienols among cereal grains (Ward et al., 2008).

The health effects of barley have been primarily attributed to the dietary fibre fraction, particularly $\beta$-glucan. Water-soluble dietary fibre can form viscous solutions, thus reducing the intestinal transit at the intestine level, delaying gastric emptying (Anderson and Bridges, 1988) and slowing glucose and sterol absorption by the intestine (Kahlon and Chow, 1997), thus lowering the serum cholesterol, postprandial blood glucose and insulin levels. Insoluble dietary fibres usually have a high waterholding capacity, which contributes to increased fecal bulk. The United States Food and Drug Administration (FDA) has allowed whole-grain barley products that can supply $\beta$-glucan at levels of $0.75 \mathrm{~g}$ per serving or $3 \mathrm{~g}$ per day to carry a claim that they reduce the risk of coronary heart disease (Anonymous, 2005). Barley is used to make coffee-like beverages and through malting to make a number of beers and speciality malts. To increase barley consumption so that it is a larger portion of 
the diet, common staple food products, such as bread and pasta, could be widely used. This kind of diet diversification provides sufficient soluble dietary fibre in the diet to bring about a remarkable improvement in human health indicators. For development of further Latvian barley breeding programmes and for creating new products there is an urgent need to increase knowledge on variation in fibre content and bioactive components in barley.

The aim of the investigation was to determine the grain composition of barley varieties and perspective breeding lines bred in Latvia and to evaluate their functional ingredients.

Sampling. The research was conducted at the State Stende Cereal Breeding Institute in 2013. The material consisted of hulled barley varieties 'Ansis', 'Austris', hulless barley varieties 'Kornelija', 'Irbe' and hulless barley breeding lines 'ST1185' and 'ST1165'. The soil type was sod podzolized sandy loam Albeluvisol (Eutric), content of organic substances $26.1 \mathrm{mg} \cdot \mathrm{kg}^{-1}$, soil $\mathrm{pH} \mathrm{KCl} \mathrm{5.6,} \mathrm{available} \mathrm{phosphorus}$ $\mathrm{P}_{2} \mathrm{O}_{5} 194.0 \mathrm{mg} \cdot \mathrm{kg}^{-1}$, and potassium $\mathrm{K}_{2} 0176.2 \mathrm{mg} \cdot \mathrm{kg}^{-1}$. Complex mineral fertiliser NPK 17:10:14 was used as a basic fertiliser at a rate $470 \mathrm{~kg}$ per ha (pure matter $\mathrm{N}-80$ $\mathrm{kg} \cdot \mathrm{ha}^{-1}, \mathrm{P} 2 \mathrm{O} 5$ - $47 \mathrm{~kg} \cdot \mathrm{ha}^{-1}$, and $\mathrm{K} 20-66 \mathrm{~kg} \cdot \mathrm{ha}^{-1}$ ) in the field trial. Mean samples from each replication $(0.5 \mathrm{~kg})$ were taken for laboratory testing, 12 samples per variety.

Chemical analysis. Test weight, protein, starch, and $\beta$-glucan contents were determined with an Infratec Analyser 1241.

Fat content was determined by Soxlet method. For determination of amino acids, dried, defatted barley samples were hydrolysed with $6 \mathrm{~N} \mathrm{HCl}$ in sealed glas tubes at $110{ }^{\circ} \mathrm{C}$ for 23 h. Amino acids were detected using reversed-phase HPLC/MS (Waters Alliance 2695, Waters 3100, column XTerra MS C18 $5 \mu \mathrm{m}, 1 \times 100 \mathrm{~mm})$ with mobile phase $(90 \%$ acetonitrile: $10 \%$ dejonized water) $0.5 \mathrm{ml} \mathrm{min} \mathrm{mi}^{-1}$, and column temperature $40{ }^{\circ} \mathrm{C}$. The identity and quantitative analysis of the amino acids was carried out by comparison with retention times and peak areas of a standard amino acid mixture. For determination of total dietary fibre (TDF), samples were incubated at $\sim 95^{\circ} \mathrm{C}$ for $30 \mathrm{~min}$ in a phosphate buffer $(\mathrm{pH}$
8.2) solution containing $100 \mu \mathrm{L}$ alfa-amylase. The $\mathrm{pH}$ was then adjusted to 7.5 and then $100 \mu$ protease was added. After incubation at $60{ }^{\circ} \mathrm{C}$ for $30 \mathrm{~min}$ the $\mathrm{pH}$ was adjusted to 4.5. Before the last incubation at $60{ }^{\circ} \mathrm{C}$ for $30 \mathrm{~min}, 200 \mu \mathrm{L}$ amyloglucosidase was added. Available carbohydrates were solubilised and the total dietary fibre (TDF) content obtained after ethanol precipitation, filtration, and drying. Duplicate samples were always processed, allowing the subtraction of protein and ash for the calculation of TDF content. $\alpha$-tocopherol was estimated as as tocol with the highest vitamin E activity. Determination of $\alpha$-tocopherol was made using high-performance liquid-chromatography according to ISO 9936-2006. Absorption was measured at $292 \mathrm{~nm}$. Chromatography was carried out in a C18 column using methanol/water liquid $(98 / 2 \mathrm{v} / \mathrm{v})$. The concentration was determined as $\mathrm{mg} \cdot \mathrm{kg}^{-1}$ in dry matter. Micronutrients of barley grain were estimated by atomic absorption spectrometry according to ISO 6869-2002.

Statistical analysis. The obtained results were statistically processed using methods of descriptive statistics, analysis of variance, and correlation analysis using programme package SPSS 20. Normal distribution was tested by a Kolmogorov-Smirnov test and homogeneity of variance by a Levene test. Correlation was defined as medium close if $0.5<\mathrm{r}>0.79$. Statistical significance was considered at probability $p<0.05$.

The results of protein, lipids, starch, dietary fibre, $\beta$-glucans and $\alpha$-tocopherol contents in hulled and hull-les barley varieties and breeding lines grain are summarised in Table 1. The content of protein in samples of barley grain depending of varieties ranged from $106.6 \mathrm{~g} \cdot \mathrm{kg}^{-1}$ to $146.8 \mathrm{~g} \cdot \mathrm{kg}^{-1}$, and the highest was in grains of hulless varieties 'Kornelija' and 'Irbe'. The difference among breeds was significant $(p<$ $0.05)$. The lipid content ranged from 20.1 to $23.5 \mathrm{~g} \cdot \mathrm{kg}^{-1}$, and did not significantly differ between varieties $(p>0.05)$. The content of $\alpha$-tocopherol in barley grain samples was from $6.03 \mathrm{mg} \cdot \mathrm{kg}^{-1}$ to $8.93 \mathrm{mg} \cdot \mathrm{kg}^{-1}$. The highest $\alpha$-tocopherol content was in grain of hulled barley varieties 'Ansis' and 'Austris', but the difference was not significant $(p>0.05)$.

Table 1

CHEMICAL COMPOSITION OF HULLED AND HULLESS BARLEY GRAIN

\begin{tabular}{|c|c|c|c|c|c|c|c|c|}
\hline $\begin{array}{l}\text { Varieties/ } \\
\text { breeding } \\
\text { line }\end{array}$ & $\begin{array}{c}\text { Protein, } \\
\mathrm{g} \cdot \mathrm{kg}-1 \\
\text { Mean } \pm \mathrm{SD}\end{array}$ & $\begin{array}{c}\text { Lipids } \\
\mathrm{g} \cdot \mathrm{kg}-1 \\
\text { Mean } \pm \text { SD }\end{array}$ & $\begin{array}{c}\alpha \text {-tocopherol, } \\
\text { mg.kg-1 } \\
\text { Mean } \pm \text { SD } \\
\end{array}$ & $\begin{array}{c}\text { TDF, } \\
\mathrm{g} \cdot \mathrm{kg}-1 \\
\text { Mean } \pm \text { SD }\end{array}$ & $\begin{array}{c}\text { IDF, } \\
\mathrm{g} \cdot \mathrm{kg}-1 \\
\text { Mean } \pm \text { SD }\end{array}$ & $\begin{array}{l}\text { SDF, } \\
\mathrm{g} \cdot \mathrm{kg}-1\end{array}$ & $\begin{array}{c}\text { Starch, } \\
\text { g.kg-1 } \\
\text { Mean } \pm \text { SD }\end{array}$ & $\begin{array}{c}\text { Total } \\
\beta \text {-glucan, g-kg-1 } \\
\text { Mean } \pm \text { SD }\end{array}$ \\
\hline Kornelija & $140.3 \pm 11.2$ & $23.5 \pm 1.5$ & $6.07 \pm 0.56$ & $194.7 \pm 29.9$ & $179.0 \pm 63.2$ & 15.7 & $623.2 \pm 6.5$ & $47.2 \pm 3.6$ \\
\hline 1165 & $110.9 \pm 8.5$ & $21.7 \pm 1.8$ & $6.03 \pm 1.17$ & $192.4 \pm 37.9$ & $160.6 \pm 6.5$ & 31.8 & $640.0 \pm 8.5$ & $49.4 \pm 1.4$ \\
\hline 1185 & $120.0 \pm 21.7$ & $20.1 \pm 2.6$ & $6.60 \pm 1.21$ & $187.4 \pm 4.4$ & $180.4 \pm 5.0$ & 7.0 & $638.7 \pm 16.6$ & $46.8 \pm 3.4$ \\
\hline Ansis & $106.6 \pm 7.4$ & $22.3 \pm 1.6$ & $8.60 \pm 1.05$ & $208.2 \pm 10.2$ & $178.6 \pm 21.6$ & 29.6 & $626.6 \pm 2.6$ & $42.8 \pm 4.5$ \\
\hline Irbe & $146.8 \pm 1.5$ & n.d. & $8.20 \pm 1.45$ & n.d. & n.d. & n.d. & $622.0 \pm 5.0$ & $46.5 \pm 3.4$ \\
\hline Austris & $138.0 \pm 1.5$ & n.d. & $8.93 \pm 1.42$ & n.d. & n.d. & n.d. & $638.0 \pm 5.0$ & $45.2 \pm 3.4$ \\
\hline Effect of variety & $\mathrm{p}<0.001$ & $\mathrm{p}>0.05$ & $\mathrm{p}>0.05$ & $\mathrm{P}>0.05$ & $\mathrm{p}>0.05$ & $\mathrm{p}>0.05$ & $\mathrm{p}<0.001$ & $\mathrm{p}>0.05$ \\
\hline
\end{tabular}

n.d. - was not determined 
COMPOSITION OF AMINO ACIDS IN HULLED AND HULLESS BARLEY GRAINS

\begin{tabular}{|c|c|c|c|c|c|c|c|c|}
\hline \multirow{3}{*}{ Amino acid } & \multicolumn{6}{|c|}{ Amino acid content, $\mathrm{g} \cdot \mathrm{kg}-1$} & \multirow{3}{*}{ Score* } & \multirow{3}{*}{ Reference** } \\
\hline & Kornelija & 1165 & 1185 & Irbe & Ansis & Austris & & \\
\hline & \multicolumn{4}{|c|}{ Hulless barley } & \multicolumn{2}{|c|}{ Hulled barley } & & \\
\hline Val & $6.22 \pm 0.62$ & $5.22 \pm 0.62$ & $5.41 \pm 0.61$ & $5.88 \pm 0.61$ & $4.94 \pm 0.26$ & $5.55 \pm 0.62$ & 5.02 & 3.9 \\
\hline Ile & $4.63 \pm 0.54$ & $3.90 \pm 0.41$ & $3.89 \pm 0.48$ & $4.04 \pm 0.48$ & $3.48 \pm 0.20$ & $4.12 \pm 0.41$ & 3.65 & 3.0 \\
\hline Leu & $8.84 \pm 0.89$ & $7.63 \pm 0.91$ & $7.50 \pm 0.78$ & $9.05 \pm 0.78$ & $7.69 \pm 0.42$ & $8.04 \pm 0.91$ & 7.29 & 5.9 \\
\hline Lys & $3.34 \pm 0.43$ & $3.51 \pm 0.26$ & $3.23 \pm 0.37$ & $4.06 \pm 0.37$ & $3.13 \pm 0.03$ & $3.59 \pm 0.26$ & 3.14 & 4.5 \\
\hline Thr & $4.15 \pm 0.34$ & $3.76 \pm 0.37$ & $3.82 \pm 0.46$ & $4.25 \pm 0.46$ & $3.59 \pm 0.20$ & $4.22 \pm 0.37$ & 3.53 & 2.3 \\
\hline Phe & $6.75 \pm 0.90$ & $5.08 \pm 0.45$ & $5.15 \pm 0.71$ & $5.93 \pm 0.71$ & $5.33 \pm 0.28$ & $5.09 \pm 0.45$ & 4.97 & 1.9 \\
\hline Met & $1.08 \pm 0.19$ & $1.12 \pm 0.20$ & $1.08 \pm 0.13$ & $0.99 \pm 0.13$ & $1.70 \pm 0.67$ & $1.09 \pm 0.20$ & 1.16 & 1.6 \\
\hline His & $3.71 \pm 0.46$ & $3.25 \pm 0.51$ & $3.32 \pm 0.48$ & $3.69 \pm 0.48$ & $3.05 \pm 0.20$ & $3.49 \pm 0.51$ & 3.06 & 1.5 \\
\hline Tyr & $3.63 \pm 0.50$ & $2.89 \pm 0.27$ & $2.88 \pm 0.23$ & $3.43 \pm 0.23$ & $2.69 \pm 0.21$ & $3.10 \pm 0.27$ & - & - \\
\hline Arg & $7.71 \pm 0.61$ & $6.76 \pm 0.49$ & $6.72 \pm 0.52$ & $7.75 \pm 0.52$ & $6.87 \pm 0.72$ & $7.32 \pm 0.49$ & - & - \\
\hline Asp & $5.95 \pm 0.41$ & $6.00 \pm 0.70$ & $5.75 \pm 0.26$ & $7.96 \pm 0.26$ & $5.55 \pm 0.13$ & $6.14 \pm 0.70$ & - & - \\
\hline Ser & $5.19 \pm 0.45$ & $4.37 \pm 0.45$ & $4.62 \pm 0.70$ & $5.13 \pm 0.70$ & $4.13 \pm 0.16$ & $5.44 \pm 0.45$ & - & - \\
\hline Glu & $35.67 \pm 4.41$ & $24.68 \pm 2.49$ & $24.60 \pm 0.54$ & $30.02 \pm 0.54$ & $24.46 \pm 1.75$ & $26.43 \pm 2.49$ & - & - \\
\hline Pro & $16.93 \pm 1.87$ & $12.18 \pm 1.61$ & $12.15 \pm 1.55$ & $14.37 \pm 1.55$ & $11.73 \pm 1.02$ & $11.87 \pm 1.61$ & & \\
\hline Gly & $4.95 \pm 0.32$ & $4.68 \pm 0.41$ & $4.60 \pm 0.54$ & $4.74 \pm 0.54$ & $4.28 \pm 0.10$ & $5.00 \pm 0.41$ & - & - \\
\hline Ala & $4.75 \pm 0.27$ & $4.48 \pm 0.37$ & $4.22 \pm 0.43$ & $4.69 \pm 0.43$ & $4.25 \pm 0.18$ & $4.62 \pm 0.37$ & - & - \\
\hline EAA & $38.71 \pm 4.29$ & $33.45 \pm 3.59$ & $33.40 \pm 3.85$ & $37.89 \pm 3.85$ & $32.90 \pm 0.89$ & $35.19 \pm 3.59$ & - & - \\
\hline PEAA & $47.01 \pm 5.49$ & $34.33 \pm 3.26$ & $35.82 \pm 4.45$ & $41.21 \pm 2.70$ & $34.02 \pm 2.70$ & $36.86 \pm 2.70$ & - & - \\
\hline EAA/T & 0.31 & 0.34 & 0.33 & 0.33 & 0.34 & 0.34 & - & - \\
\hline
\end{tabular}

EAA, the sum of indispensable amino acids $(\mathrm{Thr}+\mathrm{Val}+\mathrm{Met}+\mathrm{Ile}+\mathrm{Leu}+\mathrm{Trp}+\mathrm{His}+\mathrm{Lys})$

PEAA, the sum of partly indispensable amino acids (Arg + Glu + Tyr)

$\mathrm{EAA} / \mathrm{T}$, ratio of essential amino acids to total

* Score, amino acid g per $100 \mathrm{~g}$ protein

** Recommended by the FAO/WHO/UNU (2007) for adults

Total dietary fibre in barley grain samples ranged from $187.4 \mathrm{~g} \cdot \mathrm{kg}^{-1}$ to $208.2 \mathrm{~g} \cdot \mathrm{kg}^{-1}$ and did not differ significantly among varieties $(p>0.05)$ The soluble part of fibre varied from $7 \mathrm{~g} \cdot \mathrm{kg}^{-1}$ to $31.8 \mathrm{~g} \cdot \mathrm{kg}^{-1}$. Breeding line ' $\mathrm{ST} 1165$ ' had a higher content of soluble dietary fibre, but the difference was not significant $(p>0.05)$. The content of $\beta$-glucan in barley grain samples ranged from $42.8 \mathrm{~g} \cdot \mathrm{kg}^{-1}$ to $49.4 \mathrm{~g} \cdot \mathrm{kg}^{-1}$.

Composition of amino acids in grain of barley varieties and perspective breeding lines bred in Latvia in comparison with data from literature are shown in Table 2. The results showed that the sum of essential amino acids in barley grain samples was from $32.90 \mathrm{~g} \cdot \mathrm{kg}^{-1}$ to $37.89 \mathrm{~g} \cdot \mathrm{kg}^{-1}$. Hulless variety 'Irbe' had a higher sum of essential amino acids. Hulless barley variety 'Kornelija' had the highest content of essential amino acids valine, isoleucine, phenylalanine and histidine, and also amino acids glutamine and proline. The content of lysine varied from 3.13 to $4.06 \mathrm{~g} \cdot \mathrm{kg}^{-1}$, which was below the recommended FAO reference standard of 4.5 (Anonymous, 2007). Content of essential amino acid in $g$ protein (score) was calculated to evaluate the quality of barley grain protein. The amino acid score in comparison with amino acids requirements for human confirmed that all amino acids levels were sufficient, excepting lysine and methionine, which were below the FAO recommended reference standard (Anonymous, 2007).
Table 3

MINERAL COMPOSITION OF HULLED AND HULLESS BARLEY GRAIN

\begin{tabular}{lccccc}
\hline Variety/ & 1185 & 1165 & Kornelija & Ansis \\
\hline \multicolumn{5}{c}{ Macronutrient content (mean $\pm \mathrm{SD}), \mathrm{mg} \cdot \mathrm{kg}^{-1}$} \\
$\mathrm{~K}$ & $3911.70 \pm$ & $3723 \pm$ & $3845.33 \pm$ & $4128.33 \pm$ \\
& 224.09 & 211.16 & 389.54 & 53.13 \\
$\mathrm{Mg}$ & $1123.7 \pm$ & $1210.00 \pm$ & $1195.00 \pm$ & $1141.00 \pm$ \\
& 33.08 & 92.24 & 18.25 & 53.39 \\
$\mathrm{Ca}$ & $353.30 \pm$ & $309.33 \pm$ & $310.00 \pm$ & $323.00 \pm$ \\
& 11.61 & 10.02 & 25.94 & 2.65 \\
$\mathrm{Na}$ & $19.80 \pm$ & $18.1 \pm$ & $20.47 \pm$ & $20.87 \pm$ \\
& 1.64 & 0.20 & 0.31 & 0.50 \\
\hline \multicolumn{5}{c}{ Micronutrient content (mean $\pm \mathrm{SD}), \mathrm{mg} \cdot \mathrm{kg}^{-1}$} \\
\hline $\mathrm{Cu}$ & $2.00 \pm 0.23$ & $3.42 \pm 0.31$ & $3.35 \pm 0.54$ & $3.25 \pm 0.15$ \\
$\mathrm{Mn}$ & $11.80 \pm 1.18$ & $13.37 \pm 1.46$ & $16.37 \pm 1.80$ & $13.33 \pm 1.22$ \\
$\mathrm{Fe}$ & $31.70 \pm 0.42$ & $40.10 \pm 2.67$ & $45.07 \pm 2.44$ & $41.90 \pm 0.90$ \\
$\mathrm{Zn}$ & $17.60 \pm 0.86$ & $20.57 \pm 0.87$ & $23.80 \pm 1.93$ & $18.77 \pm 0.71$
\end{tabular}

The contents of macronutrients and micronutrients in barley varieties and perspective breeding lines are summarised in Table 3. Hulled variety 'Ansis' is had highest levels of macronutrients $\mathrm{K}, \mathrm{Ca}$ and $\mathrm{Na}$, and the new hulless variety 'Kornelija' has higher $\mathrm{Cu}, \mathrm{Mn}, \mathrm{Fe}$ and $\mathrm{Zn}$ content.

The results of evaluated chemical composition of new barley varieties and perspective breeding lines presented in this 
paper are similar with other research findings, where protein content in barley was reported $8-17 \%$, lipids $2-3 \%$, and starch 65-68\% (Baik and Ullrich, 2008). As it is known starch, fibre and protein make up the largest portion of the kernel, and variation in one of these components will influence the amounts of the other two. There was notable variation in protein among the barley varieties and breeding lines. The difference between average protein content in different varieties was $39.8 \mathrm{~g} \cdot \mathrm{kg}^{-1}$. Other studies have also found that barley protein content is highly dependent on the cultivar (Qi et al., 2006) and differs with the growth conditions, particularly with the rate and timing of nitrogen fertilisation (Arendt and Zannini, 2013). Crude protein values in hulless breeding lines were lower than determined in earlier studies - average from 133.0 to $188.2 \mathrm{~g} \cdot \mathrm{kg}^{-1}$ in 2010 and from 145.1 to $183.2 \mathrm{~g} \cdot \mathrm{kg}^{-1}$ in 2011. Significantly higher crude protein for hulless barley breeding lines was observed in 2011, compared to those in 2010 (Bleidere et al., 2013).

Among cereals, barley can be a good source of vitamin E, which is an important phytochemical compound with antioxidant activity and potential benefits for human health. The amount of $\alpha$-tocopherol determined in this study (6.03 $\mathrm{mg} \cdot \mathrm{kg}^{-1}$ to $8.93 \mathrm{mg} \cdot \mathrm{kg}^{-1}$ ) was lower in comparison with other studies, where for hulless varieties $\alpha$-tocopherol content varied from 8.4 to $10.1 \mathrm{mg} \cdot \mathrm{kg}^{-1}$, and for hulled varieties from $8.4-8.6 \mathrm{~g} \cdot \mathrm{kg}^{-1}$ (Cavarelo et al., 2004). Also, $\alpha$-tocopherol content in this study was higher than in our earlier studies, where it ranged from $3.7 \mathrm{mg} \cdot \mathrm{kg}^{-1}$ to $8.7 \mathrm{mg} \cdot \mathrm{kg}^{-1}$, and $\alpha$-tocopherol content for variety 'Irbe' was $7.9 \mathrm{mg} \cdot \mathrm{kg}^{-1}$ and for 'Ansis' $6.5 \mathrm{mg} \cdot \mathrm{kg}^{-1}$ (Bleidere et al., 2013). These differences can be associated with effect of the environment, as individual forms of tocopherols and tocotrienols accumulate with different kinetics during barley grain development (Arendt and Zannini, 2013). Cavarelo et al. (2004) found that both genotype and environment affected total tocol content.

The results of the study summarised in Table 1 show that all barley varieties had high total dietary fibre content (18.7 to $19.5 \mathrm{~g}$ per $100 \mathrm{~g}$ ), in comparison with values in a review by (Fasnaught, 2001) where total dietary fibre of barley grain ranged from 11 to $34 \mathrm{~g}$ per $100 \mathrm{~g}$ and soluble dietary fibre from 3 to $20 \mathrm{~g}$ per $100 \mathrm{~g}$. Hulless barley grain typically contains less total dietary fibre, in the range of $11-20 \%$, with $11-14 \%$ for insoluble dietary fibre and $3-10 \%$ for soluble dietary fibre. Unfortunately, soluble dietary fibre in tested grains was not higher than $3.2 \mathrm{~g}$ per $100 \mathrm{~g}$ ('ST1165'). Of all the TDF components in barley, $\beta$-glucan is probably the most important in terms of human diet and health benefits. The barley grain usually contains $2-10 \mathrm{~g} \beta$-glucan in $100 \mathrm{~g}$ dry matter, with genotype having the greatest effect (Arendt and Zannini, 2013). The results of this investigation demonstrated that the highest $\beta$-glucan content was in the new hulless variety 'Kornelija' and perspective breeding line 'ST1165', in which $\beta$-glucan content was $47.2 \mathrm{~g} \cdot \mathrm{kg}^{-1}$ and $49.4 \mathrm{~g} \cdot \mathrm{kg}^{-1}$, respectively.

Amino acid composition of barley protein is quite similar to that of other cereal grains (Arendt and Zannini, 2013). High glutamic acid and proline contents and relatively low amounts of basic amino acids characterise the barley grain (Newman and Newman, 2005). In particular, hulled barley protein is slightly higher in lysine content than that of hulless barley (Newman and Newman, 2005). Average content of amino acids valine, lysine, threonine, histidine, arginine and alanine in all tested barley varieties and breeding lines was higher than mentioned in literature (Arendt and Zannini, 2013). The results of this study showed that the highest contents of essential amino acids, particularly valine, isoleucine, phenilalanine, histidine and lysine, and also glutamic acid and proline are in new hulless variety 'Kornelija'.

In most cereal increasing the protein content results in a relative increase in the prolamin fraction (generally low in lysine content) and, as a result, overall protein quality; therefore, a negative relationship of lysine to overall protein content is typical in cereal grain (Arendt and Zannini, 2013). The study showed that protein and lysine content in barley grain had a weak positive correlation $r=0.34(p<$ $0.05)$, which is in contrast with previous studies. Lysine content ranged from $3.13 \mathrm{~g} \mathrm{~kg}^{-1}$ (hulled variety 'Ansis') to $4.06 \mathrm{~g} \cdot \mathrm{kg}^{-1}$ (hulless variety 'Irbe'), and these values are similar to those reported $\left(4.1 \mathrm{~g} \cdot \mathrm{kg}^{-1}\right)$ for hulless barley (Newman and Newman, 2005).

There are two important aspects of protein quality: 1) the characteristics of the protein and the food matrix in which it is consumed, and 2) the demands of the individual consuming the food. Recommended intake (FAO/WHO) of total essential amino acids is $83.5 \mathrm{mg}$ per $\mathrm{kg}$ body weight per day, or $5.8 \mathrm{~g}$ per human with body weight $70 \mathrm{~kg}$ (http://www.healthknot.com/protein_requirement.html\#subject). The results of this study demonstrated that the average sum of essential amino acids in barley grains was $31.81 \mathrm{~g} \cdot \mathrm{kg}^{-1}$, particularly, and for hulless variety 'Kornelija' $38.71 \mathrm{~g} \cdot \mathrm{kg}^{-1}$ ', which is higher than that reported for hulled varieties $30.0 \mathrm{~g} \cdot \mathrm{kg}^{-1}$, and for hulless varieties - $33.5 \mathrm{~g} \cdot \mathrm{kg}^{-1}$ (Newman and Newman, 2005).

Comparison of the amino acid composition of barley grain samples with the levels of essential amino acid recommended by the FAO/WHO/UNU for adults shows that barley is deficient in only lysine and methionine, and that some essential amino acids, namely valine, phenilalanine and histidine are present in considerably higher amounts. The amount of phenilalanine $\left(4.97 \mathrm{~g} \cdot \mathrm{kg}^{-1}\right)$ was 2.6 times higher as recommended. Since net protein utilisation is affected by the limiting amino acid (the sum of phenylalanine and tyrosine), barley grains can be evaluated as a source of protein with high biological value - the average sum of phenylalanine and tyrosine in this study was $7.75 \mathrm{~g} \cdot \mathrm{kg}^{-1}$, in grains of hulless variety 'Kornelija' $-10.38 \mathrm{~g} \cdot \mathrm{kg}^{-1}$, in grains of variety 'Ansis' $-8.92 \mathrm{~g} \cdot \mathrm{kg}^{-1}$.

Among the micro-elements, $\mathrm{Fe}, \mathrm{Mn}$, and $\mathrm{Zn}$ are the main representatives in barley grains. The hulless variety 'Kornelija' had higher micronutrient amount. In comparison with hulled variety 'Ansis', 'Kornelija' had a higher content 
of $\mathrm{Cu}, \mathrm{Mn}, \mathrm{Fe}$ and $\mathrm{Zn}:+0.2 \mathrm{mg} \cdot \mathrm{kg}^{-1},+3.04 \mathrm{mg} \cdot \mathrm{kg}^{-1},+3.17$ $\mathrm{mg} \cdot \mathrm{kg}^{-1}$ and $+5.03 \mathrm{mg} \cdot \mathrm{kg}^{-1}$, respectively. The highest $\mathrm{K}$ content was found in grain of variety 'Ansis' $-4.13 \mathrm{~g} \cdot \mathrm{kg}^{-1}$. Average $\mathrm{K}$ content reported by Newman and Newman (2008) was $4.52 \mathrm{~g} \cdot \mathrm{kg}^{-1}$, and average $\mathrm{Cu}, \mathrm{Mn}, \mathrm{Fe}$ and $\mathrm{Zn}$ contents were $4.98 \mathrm{mg} \cdot \mathrm{kg}^{-1}, 19.43 \mathrm{mg} \cdot \mathrm{kg}^{-1}, 36 \mathrm{mg} \cdot \mathrm{kg}^{-1}$ and $27.7 \mathrm{mg} \cdot \mathrm{kg}^{-1}$, respectively.

In general, the contents of total dietary fibre, protein, sum of essential amino acids of the described barley varieties and perspective breeding lines bred in Latvia suggest that there are many possibilities of using barley in food products with high biological value. Hulless barley, particularly, variety 'Kornelija', could be used for several potential new applications as a wholegrain ingredient in value-added products.

\section{ACKNOWLEDGMENT}

Publication and dissemination of research results has been made due to the funding of the European Social Fund (ESF) co-financed Project Nr. 1DP/1.1.1.2/13/APIA/VIAA/032.

\section{REFERENCES}

Anderson, W., Bridges, E. S. (1988). Dietary fiber content of selected foods. Amer. J. Clin. Nutr., 47, 440-447.

Andersson, A. A. M., Lampi, A.-M., Nyströ, M. L., Piironen, V., Li, L., Ward, J. L., Gebruers, K., Courtin, C. M., Delcour, J. A., Boros, D., Fras, A., Dynkowska, W., Rakszegi, M., Bedő, Z., Shewry, P. R., Aman, P. (2008). Phytochemical and dietary fiber components in barley varieties in the HEALTHGRAIN diversity screen. J. Agr. Food Chem., 56, 9767-9776.

Anonymous (2005). FDA allows barley products to claim reduction in risk of coronary heart disease. FDA news release, 23 December. Available at: http://www.fda.gov/NewsEvents/Newsroom/PressAnnouncements/ 2005/ ucm108543.htm (accessed November 2012).

Anonymous (2007). Protein and amino acid requirements in human nutrition. Report of a Joint WHO/FAO/UNU Expert Consultation, World Health Organization Technical Report Series 935, Geneva.

Arendt, E. K., Zannini, E. (2013). Cereal Grains for the Food and Beverage Industries. Woodhead Publishing, Cambridge. 485.
Baik, B.-K., Ullrich, S. E. (2008). Barley for food: Characteristics, improvement, and renewed interest. J. Cereal Sci., 48, 233-242.

Bleidere, M., Zute, S., Jākobsone, I. (2013). Characterisation of physical and biochemical traits of hulless spring barley grain in Latvian breeding programme. Proc. Latvian Acad. Sci., Section B, 67 (4/5), 399-404.

Cavarelo, A., Gianineti, A., Finocchiaro, D. A., Stanca, A. M. (2004). Tocols in hull-less and hulled barley genotypes grown in contrasting environments. J. Cereal Sci., 39, 175-180.

Duffus, C. M., Cochrane, M. P. (1993). Formation of the barley grain - Morphology, physiology and biochemistry. In: Macgregor, A. W., Bhatty, R. S. (eds.). Barley: Chemistry and Technology. AACC International Inc., St. Paul, MN, pp. 31-72.

Fastnaught, C. E. (2001). Barley fiber. In: Deher, C. M. (ed.). Handbook of Dietary Fiber. Marcel Dekker, New York, pp. 519-542.

Kahlon, T. S., Chow, F. I. (1997). Hypocholesterolemic effects of oat, rice, and barley dietary fibers and fractions. Cereal Foods World, 42, 86-92.

Kerckhoffs, D. A. J. M., Brouns, F., Hornstra, G., Mensink, R. P. (2002). Effects on the human serum lipoprotein profile of $\beta$-glucan, soy protein and isoflavones, plant sterols and stanols, garlic and tocotrienols. J. Nutr., 132, 2494-2505.

Morrison, W. R. (1978). Cereal lipids. In: Advances in Cereal Science and Technology, Vol. 2. Y. Pomeranz (ed.). American Association of Cereal Chemists, St. Paul, MN, pp. 228-348.

Newman, C. W., Newman, R. K. (2005). Hulless barley for food and feed. In: Abdelaal, E., Wood, P. (eds.). Specialty Grains for Food and Feed. AACC International, Inc., St Paul, MN, pp. 167-202.

Qi, J. C., Zhang, G. P., Zhou, M. X. (2006). Protein and hordein content in barley seeds as affected by nitrogen level and their relationship to beta-amylase activity. J. Cereal Sci., 43, 102-107.

Ward, J. L., Poutanen, K., Gebruers, K., Piironen, V., Lampi, A.-M., Nyströ, M. L., Andersson, A. A. M., Åman, P., Boros, D., Rakszegi, M., Bedő, Z. and Shewry, P. R. (2008). The HEALTHGRAIN cereal diversity screen: Concept, results, and prospects. J. Agr. Food Chem., 56, 9699-9709.

Welch, R.W. (1978). Genotypic variation in oil and protein in barley grain. $J$. Sci. Food Agr., 29, 953-958.

Zielinski, H., Ciska, E., Kozlowska, H. (2001). The cereal grains: Focus on vitamin E, Czech. J. Food Sci., 19, 182-188. Available at: http://www.healthknot.com/protein_requirement.html\#subject (accessed 8 April 2015).

Received 20 July 2015

\section{MIEŽU GRAUDU SASTĀVS UN FUNKCIONĀLĀS SASTĀVDALAS}

Graudi, tostarp arī mieži, ir atzīti funkcionāli produkti, jo labvēlīgi ietekmē patērētāja veselību un samazina vairāku slimību risku. Šodien miežu patērinšs pārtikā ir loti zems. Tomēr pētījumi, kas parādījuši, ka mieži ir bagātīgs diētisko škiedrvielu, īpaši $\beta$-glikānu avots, sekmējuši interesi par to plašāku izmantošanu pārtikas produktos. Miežiem raksturīgs zems tauku saturs, labi sabalansēts aminoskābju sastāvs, tie ir vitamīnu (tostarp E vitamīna) un polifenolu avots uzturā. Pievēršot lielāku patērētāju un ražotāju uzmanību miežu un to produktu uzturvērtỉbai, pastāv iespēja iekḷaut miežus pārtikas produktu sastāvā un veicināt to lietošanu uzturā. Tāpēc pētījuma mērkis bija analizēt Latvijā izveidoto, jauno miežu škirṇu un perspektīvo līniju graudus un izvērtēt to funkcionālās sastāvdaḷas. Miežu paraugos tika noteikts olbaltumvielu, tauku, cietes, diētisko škiedrvielu, $\beta$-glikānu, $\alpha$-tokoferola saturs un aminoskābju sastāvs. Pētījuma rezultāti liecina, ka olbaltumvielu daudzums miežu graudos dažāāām škirnēm tika noteikts no $106.6 \mathrm{~g} \cdot \mathrm{kg}^{-1} \mathrm{l} \mathrm{dz} 146.8 \mathrm{~g} \cdot \mathrm{kg}^{-1}$, diētiskās škiedrvielas $187.4 \mathrm{~g} \cdot \mathrm{kg}^{-1}$ $208.2 \mathrm{~g} \cdot \mathrm{kg}^{-1}, \beta$-glikāni $4.28 \mathrm{~g} 100 \mathrm{~g}^{-1}-4.94 \mathrm{~g} 100 \mathrm{~g}^{-1}$ un $\alpha$-tokoferola saturs $6.03 \mathrm{mg} \cdot \mathrm{kg}^{-1}-8.93 \mathrm{mg} \cdot \mathrm{kg}^{-1}$. Neaizstājamo aminoskābju summa miežu graudu paraugos aprēḳināta no $32.90 \mathrm{~g} \cdot \mathrm{kg}^{-1}$ līdz $38.71 \mathrm{~g} \cdot \mathrm{kg}^{-1}$. Gan plēkšņgraudu, gan kailgraudu miežu graudi vērtējami kā augstvērtīgs olbaltumvielu avots ar augstu bioloğisko vērtỉbu. Miežu sastāvā esošās funkcionālās sastāvdaḷas varētu veicināt to plašāaku izmantošanu pārtikā. 